\title{
The analysis of factors influencing the sustainability of forest stands
}

\author{
Vera Savchenkova ${ }^{1,}$, Sergey Vasiliev ${ }^{1}$, Vladimir Nikitin $^{1}$, and Elena Runova ${ }^{2}$ \\ ${ }^{1}$ Mytishschi branch of Bauman Moscow State Technical University, 2nd Baumanskaya str., 5, bld. 1, \\ Mytishchi, 141005, Russia \\ ${ }^{2}$ Bratsk State University, Makarenko str., 40, Bratsk, 665709, Russia
}

\begin{abstract}
The problem of the ecological state of the microclimate of the modern metropolis and surrounding areas is becoming more and more urgent every year due to the increasing anthropogenic impact. This is why it is necessary to conduct a systematic assessment of the state of green spaces in order to design a set of measures to improve their sustainability, preserve biological diversity and improve the environment. The study of tree planting was carried out in an instrumental and visual way. The assessment of natural renewal was carried out on a differentiated scale of the state and quality of natural renewal under the canopy of forest plantations. The purpose of the study was to identify factors that affect the intensity of damage to tree stands, predict the volume of dead trees, and develop an approach to improving the stability of forest stands. As a result, is has been stated that storm damage has mainly affected weak, mature and overmature trees. Root rot (i.e., spruce root rot) promotes high degree of windthrow, while stem rot provokes windbreak (which is typical for hardwood species - aspen, birch, lime tree). The greatest influence on the intensity of damage to plantings by windfall and windbreak has the length of the crown, the diameter of the trunk and the content of rot. Based on the results of the research a new approach of regenerating species composition and the structure of local forest types at the national park has been proposed.
\end{abstract}

\section{Introduction}

The problem of adequate combination of human activity with environment is relevant today due to the intense development of urban infrastructure and expansion of metropolis [1-3]. Federal national park "Losiniy osrtov" (Elk island) is the largest forestland situated in the Moscow region. Significant areas of its forest stand mainly containing forest forming species (more than $600 \mathrm{ha}$ ) have been lost due to multiple storms from 2001 to 2017 as well as due to the total affect of spruce stands by eight-toothed bark beetle. Designing clearing and regeneration treatments requires preliminary evaluation of its sanitary and forest pathological condition.

\footnotetext{
* Corresponding author: v9651658826@yandex.ru
} 
A study area at the first step was Losinoostrovskaya forest district (further - historical part of the Park). Taking into consideration constant changings of forest ecosystems and according to the forest legislation requirements a systematic environmental monitoring including forest stands conditions is being organized on the territory of the Park in order to detect undesirable deviations in due time.

Despite ambitious forest restoration plans in the historical part of the Park, the territories of real forest planting were 855 ha in 1956 in comparison with planned areas of 1907 ha.

The consequences of drought and war times had been eliminated only by 1964 . There were 298 ha of non-forested areas in 1966, and only 43 ha in 1976. Forest inventory in 1966 showed that the territory of forest plantations was 596 ha with viability of $60 \%$.

From the history of forest management, it is known that serious windthrow happened several times, in particular in 1860-1884, 1878-1884, 1904, 1915, 1943-44 and 1960s. At the boundary between XIX-XX centuries the object of windthrow damage was mainly old spruce stands on the whole territory of the Park. Later in the 1940s all forest stands of all species turned to be damaged on the whole territory of the Park as well.

Any mass damage of forest stands (in particular, windthrow) can be considered as an indicator of low forest ecosystem sustainability as a whole. The possibility of windthrow and windbreak depends on a wind type, season, tree species, environmental conditions, tree age, its condition, soils properties, species composition of a stand, level of forest management and others.

On the edge of forest and open space the speed of air masses increases approximately by half, turbulent wind flows appear, its power depending on temperature difference between forest and open space. During storm average linear wind speed has reached 24 mps. The average annual wind speed at the Park is 4 mps. The strongest winds are usually in January, March and November. Mainly there are north-west and south-west winds. Averagely there are 20 days with wind speed more than $15 \mathrm{mps}$ every year. Massive windbreak and windthrow usually happen at wind speed of 15-25 mps.

\section{Materials and methods}

On-site investigation was made by land technique, by instrumental and visual method, providing the necessary accuracy of sanitary and forest pathological condition estimation.

The following parameters have been estimated: prevailing species, undergrowth, understory, forest cover (indicators), volume and species of windthrow and windbreak, location of plots, damaged by windthrow and windbreak.

At the first step sample plots were investigated and were chosen those with visible consequences of negative factors impact. Sample plots were grouped according to the level of damage, species composition, age, the percentage of lost trees was estimated approximately. Then a complete enumeration was made on sample plots indicating diameters, heights, categories of condition, growth class and characteristics of damage for every tree. Registration cards were completed.

After that the collected data was analyzed and all the materials were grouped according to the characteristics of damage, species, age, site index and category of sanitary condition.

Comparison of the data from the second on-site investigation with the first ones collected on sample plots allowed us to find out lost trees and analyze their sanitary condition at the moment of death or damage. Thus, a correlation between stands sustainability and their sanitary conditions stand structure. Damaged stands vary according to the level of harm: serious damage - more than $50 \%$ of stand is windthrow, medium damage $-25-50 \%$, light damage - up to $25 \%$.

Based on the changings in stand density the following condition was accepted: 
Having the density around $0.7-0.8$ the loss up to $25 \%$ does not lead to a substantial decrease in density of forest layers (density equals to $0.5-0.6$ ). Losing more than $50 \%$ leads to the decrease in density up to $0.3-0.4$ and less, if the density is less than 0.3 the area is not considered forested any more.

Forest pathological estimation of stands in the city zones of the Park including areas of windthrow has been done with the reference to the data of forest pathological monitoring from 1994 to 1998 as well as to on-site examinations in 2017. In total during field trips in the city zones of the Park we investigated 73 areas of windthrow with the territory of 129 ha, including 34 cleared areas of 54 ha and 39 non-cleared areas of 75 ha.

Estimation of natural regeneration progress of main forest forming species has been done on the basis of the individual enumeration data of undergrowth on sample plots as well as on 1 ha. For each tree species we defined the number of undergrowth depending on age, size, occurrence, quality of undergrowth, share of establishing undergrowth. Undergrowth was recorded with the help of a method tested by Central research institute of mechanization and energetics of forest industry as well as by Russian Research Institute for Silviculture and Mechanization of Forestry on circle plots with the radius $1.78 \mathrm{~m}$ and 1.26 $\mathrm{m}$ and territory of 10 and 5 sq.m.

Survey lines were allocated on sample plots diagonally or parallel depending on the territory of the plot. Plots with the total area of 10 sq.m. were situated each $10 \mathrm{~m}$.

Undergrowth was divided into three categories according to its height: low - up to 0.5 $\mathrm{m}$; medium - from 0.51 to $1.5 \mathrm{~m}$ and high - more than $1.5 \mathrm{~m}$.

Depending on its qualitative features undergrowth fell into three categories: viable, doubtful and inviable. Viable undergrowth had dense needle coverage, green or dark-green needles, well-defined whorled arrangement, well-developed canopy and stems with smooth or small-scaled bark without visible damage.

Doubtful undergrowth was considered as specimen potential abilities of which were hard to predict. Inviable undergrowth was that having critical suppression or dried undergrowth.

To estimate the viability of undergrowth we used the following characteristics: easy mechanical bark damage to the stem which is not more than $1 / 4$ of the circuit and averagely not more than $0.5 \mathrm{~cm}$ wide for low undergrowth, $2 \mathrm{~cm}$ for medium and $3.5 \mathrm{~cm}$ for high; angle of the stem is up to $20^{\circ}$ for low and up to $10^{\circ}$ for medium and high; damage of canopy in the form of separate branches damage.

We investigated 34 plots in detail including 5 non-treated. Investigated areas of stands were of two forest types: composite spruce forest with broadleaved grasses $\left(\mathrm{S}_{\mathrm{cbg}}\right)$, which has relatively rich mesophilic soils $\mathrm{C}_{2}$ and relatively rich mesohydrophilic soils $\mathrm{C}_{3}$; composite spruce forest with small-leaved grasses $\left(\mathrm{S}_{\mathrm{csg}}\right), \mathrm{C}_{3}$. The biggest group of forest types (composite with broadleaved grasses - CBG) occupied stands with mainly Norway spruce (Picea abies) (3 plots), small-leaved lime (Tilia cordata) (6 plots) and silver birch (Betula Pendula) (3 plots).

In order to estimate the effect of windthrow and windbreak on lower levels the condition of lower levels was studied. Recreation impact was evaluated by the condition of trail and road network. The impact of storm on soil is related to its consequences in the forest. So, the types of soil cover ruptures caused by root system of windthrow trees can tell us about the sizes of exposed mineral soil including its horizon. The easiest thing to do is to identify the impact of logging on soil. During this research the degree of soil damage was expressed in per cents.

Composition of forest cover and its dynamics largely depend on the kind of soil damage, which in turn defines how well regeneration will occur. Moreover, forest cover, undergrowth and understory on test sites have been studied. As a result, registers describing forest cover and undergrowth have been compiled. 
In laboratory conditions the following parameters were identified: average number and composition of undergrowth (in equivalent to large-sized undergrowth trees), occurrence, average number and composition of living young trees more than $3 \mathrm{~m}$ high, total projective cover, occurrence of forest cover types and understory; a scheme was created to calculated the necessary number of planting material taking into account viable undergrowth.

Having examined cleared-up areas according to its functional purpose, we allocated sites for the primary restoration work.

On non-cleared areas in order to identify the reasons of low sustainability of the stand we measured morphological parameters of both windthrow and standing trees, taking a record of pest and disease damage as well. 310 windblown and 270 standing trees were described in total. For fallen trees we measured tree girth, height, crown length and diameter, height, width and thickness of root lump using tape measure; visually estimated root system (root rot presence). While measuring fallen trees we took only those which fell down due to strong wind without additional load of other trees which fell on them. For standing trees, we measured tree girth at $1.3 \mathrm{~m}$ height and its height and crown size using altimeter. Stands origin (seed or coppice) was identified by the presence or absence of so called "mirror" at the root collar. Additional characteristics of coppice origin especially for a lime tree is its being multi-stemmed.

Doing laboratory work separately for standing and fallen trees we found the following indicators: average taxation diameter; average height (in height graph); average relative crown length (in per cent); average relation of crown length to its width, average thickness of root lump, average volume of root lump, per cent of trees having root rot.

A tally sheet for every plot of non-cleared windthrow was made.

To analyze general wind sustainability of a city part of the Park a database of windthrow areas was compiled.

\section{Results}

The territory of the Park is represented by a single forest land and the same category of recreational forests - zone of moderate attendance depending on allocated functional areas. Besides, separate areas are experiencing increasing recreational loads.

Vegetation cover in the Park is represented by the areas of coniferous forests of taiga type, coniferous-broadleaved forests, broadleaved forests as well as marshy meadows and bogs of different types. The main forest forming species are Silver birch (Betula Pendula Roth), Norway spruce (Picea abies (L.) H. Karst.), Small-leaved Lime tree (Tilia cordata Mill.), Scots pine (Pinus Sylvestrys L.), European larch Laryx Decidua Mill.) together with European oak (Quercus robur L.) and Aspen (Populus Tremula L.). The majority of birch forests and lime tree forests in the city part of the Park are of $7^{\text {th }}$ age class (70 years and older). Lime stands take the biggest share in these old forests, mainly having trees of 90120 years old. The majority of Norway spruce stands are also of 90-120 years old. Scots pine and European larch stands are of 3-4 age class (40-70 years old) - these are plantations made in first years after the War.

The object of our research is windthrow and windbreak areas of forest in the following compartments: 28-29, 31-32 study and excursion zone, especially protected areas; 7 and 13 - recreation zone.

The biggest part of windthrow damage of 2017 occurred in study and excursion zone of the city part of the Park. Both areas mainly have mature and over mature stands. Damaged stands are mainly birch.

Both naturally regenerated stands and planted ones were damaged by windthrow. Mainly damaged stands were plantations of European larch of 1952 and 1973 as well as plantation of Silver birch of 1948 and 1954. The volume of windthrow and windbreak 
occurred in 2017 in the city part of the Park is more than $1600 \mathrm{~m}^{3}$. Table 1 shows the results of examining areas mostly damaged by windthrow and windbreak. Age of tree species is given based on forest management data of 1988 taking into account the difference in period of time relatively to the year of research (2017).

Table 1. Results of evaluation of the largest forest areas in the city part of the Park damaged by windthrow

\begin{tabular}{|c|c|c|c|c|c|}
\hline $\begin{array}{l}\text { Com } \\
\text { partm } \\
\text { ent }\end{array}$ & $\begin{array}{l}\text { Subcompa } \\
\text { rtment }\end{array}$ & Unit & $\begin{array}{l}\text { Tree species in } \\
\text { windthrow and } \\
\text { windbreak }\end{array}$ & $\begin{array}{c}\text { Volume of } \\
\text { windthrow and } \\
\text { windbreak, \% } \\
\left(\mathrm{m}^{3}\right)\end{array}$ & Growing conditions \\
\hline 32 & 1 & $3-4$ & $\begin{array}{l}\text { Lime (110 yrs), } \\
\text { Pine (120 yrs) }\end{array}$ & $40 \%\left(240 \mathrm{~m}^{3}\right)$ & $\begin{array}{l}\mathrm{CBG}, \mathrm{C}_{2} ; \mathrm{CSG}, \mathrm{C}_{2} \text {. Indicators } \\
\text { - avens, sedge, bush grass } \\
\text { Understory - hazel, rowan. } \\
\text { Main undergrowth - lime tree } \\
\text { (up to } 1.0 \text { thousand } \mathrm{sp} / \mathrm{ha} \text { ) }\end{array}$ \\
\hline $32-16$ & $\begin{array}{l}\text { in } 32-1 \\
\text { in } 16-4\end{array}$ & $\begin{array}{l}\text { in } 32-1 \\
\text { in } 16- \\
14,16\end{array}$ & Spruce (120 yrs) & $40 \%\left(260 \mathrm{~m}^{3}\right)$ & $\begin{array}{l}\mathrm{CBG}, \mathrm{C}_{2} \text {. Indicators - } \\
\text { goutweed, sedge, weasel } \\
\text { snout, bush grass. Understory } \\
\text { - hazel, rowan. Main } \\
\text { undergrowth - lime tree (up to } \\
1.0 \text { thousand sp/ha) }\end{array}$ \\
\hline 32 & 3 & 7 & $\begin{array}{l}\text { Spruce+Birch } \\
(105 \mathrm{yrs})\end{array}$ & $\begin{array}{l}40 \% \text { (+bark } \\
\text { beetle) } \\
\left(220 \mathrm{~m}^{3}\right)\end{array}$ & $\begin{array}{l}\text { CBG, } \mathrm{C}_{2} \\
\text { Indicators - goutweed, hazel } \\
\text { wort, horsetail, weasel snout, } \\
\text { bush grass, lime grass. } \\
\text { Understory - rowan, } \\
\text { honeysuckle, hazel; } \\
\text { Main undergrowth - lime tree } \\
\text { (up to } 1.0 \text { thousand sp/ha) }\end{array}$ \\
\hline 29-31 & 2 & 11 & Birch (70 yrs) & $100 \%\left(350 \mathrm{~m}^{3}\right)$ & $\begin{array}{l}\mathrm{CBG}, \mathrm{C}_{2} \\
\text { Indicators - goutweed, sedge, } \\
\text { weasel snout. Understory - } \\
\text { rowan, honeysuckle, } \\
\text { buckthorn - rarely. Main } \\
\text { undergrowth - spruce tree (up } \\
\text { to } 1,5 \text { thousand sp/ha) }\end{array}$ \\
\hline 27 & 1 & $20,21,23$ & $\begin{array}{l}\text { Larch }(66 \mathrm{yrs})- \\
\text { Birch }(70 \mathrm{yrs})\end{array}$ & $\begin{array}{l}40 \%\left(300 \mathrm{~m}^{3}\right) \\
\text { unevenly }\end{array}$ & $\begin{array}{l}\text { Plantations of } 1952 \text { and } 1973 \\
\text { CSG, C3. Indicators- } \\
\text { goutweed, May lily, weasel } \\
\text { snout, cereal, bush grass } \\
\text { Understory - rowan, elder; }\end{array}$ \\
\hline 13 & 1 & 11 & Birch (70 yrs) & $50 \%\left(300 \mathrm{~m}^{3}\right)$ & $\begin{array}{l}\mathrm{CSG} \mathrm{C}_{3} \text {; Indicators - cereal, } \\
\text { gout weed, hazel wort, lime } \\
\text { grass. Understory - dog } \\
\text { wood, buckthorn, willow. } \\
\text { Main undergrowth - oak, } \\
\text { lime (up to } 1,0 \text { thousand } \\
\text { sp/ha) }\end{array}$ \\
\hline
\end{tabular}


As a result of the evaluation of current sanitary and forest pathological condition of forest stands including data from table 1, it was stated that forest areas of city part of the Park are partly damaged by windthrow and windbreak; aesthetical evaluation is partially lowered; passableness and visibility are medium; main part of forest is overmature stand; natural regeneration of main species is good (more than 2.0 thousand $\mathrm{sp} / \mathrm{ha}$ ); soils are wet and fresh, fertile and weak.

In general, the list of species susceptible to wind damage include spruce, birch and lime. Wind resistant tree species are oak, larch, pine, alder, maple. Soil and hydrological factors have a huge impact on wind resistance. Badly aerated heavy and wet soils prevent the development of deep root system as a result of which even pine and larch become susceptible to wind. On the contrary, spruce sustainability increases on well drained clay loam soils.

The territory of this region is mainly represented by soddy-podzolic gleyic soils. While examining forest areas damaged by windthrow with the help of indicator plants and the presence of humidity it was identified that soils are seriously dampened, somewhere water is even stagnant.

Wind resistance decreases with the age of a tree and depends on its height (lever arm is becoming longer) and on the crown size (are of impact increases). Certain differences were found according to growth classes (defined by the height and crown development). In most cases windthrow trees belonged to higher classes. Higher trees with well-developed crown were subject to wind damage. Trees of 3-5 growth class (second layer, undergrowth, understory) are as a rule fallen by windthrow trees of the first layer. Sanitary condition of the stands became worse due to damage to standing trees by falling stems (table 2).

In 2001 windthrow mainly damaged coppice stands with several stems growing from one root. During windthrow of 2017 trees of seed origin were damaged.

Table 2. Changing characteristics of 1 layer stands on damaged forest areas

\begin{tabular}{|c|c|c|c|c|c|}
\hline \multirow[t]{2}{*}{ Tree species } & $\begin{array}{l}\text { Average } \\
\text { height by } \\
\text { year, } m\end{array}$ & $\begin{array}{c}\text { Average } \\
\text { diameter by } \\
\text { year, cm }\end{array}$ & $\begin{array}{c}\text { Stock by year, } \\
\mathrm{m}^{3} / \mathrm{ha}\end{array}$ & $\begin{array}{c}\text { Relative } \\
\text { density by } \\
\text { year }\end{array}$ & $\begin{array}{c}\text { Point of } \\
\text { condition } \\
\text { category, } \\
\text { by year }\end{array}$ \\
\hline & $\frac{1998}{2017}$ & $\frac{1998}{2017}$ & $\frac{1998}{2017}$ & $\frac{1998}{2017}$ & $\frac{1998}{2017}$ \\
\hline $\begin{array}{c}\text { Small- } \\
\text { leaved lime } \\
\text { tree }\end{array}$ & $\frac{27}{36}$ & $\frac{28}{32}$ & $\frac{370}{210}$ & $\frac{0,8}{0,5}$ & $\frac{1,3}{2,4}$ \\
\hline $\begin{array}{c}\text { Norway } \\
\text { spruce }\end{array}$ & $\frac{22}{27}$ & $\frac{27}{34}$ & $\frac{360}{220}$ & $\frac{0,8}{0,5}$ & $\frac{1,5}{2,8}$ \\
\hline $\begin{array}{c}\text { European } \\
\text { larch }\end{array}$ & $\frac{19}{28}$ & $\frac{20}{23}$ & $\frac{260}{180}$ & $\frac{0,7}{0,4}$ & $\frac{1,2}{1,9}$ \\
\hline Silver birch & $\frac{24}{28}$ & $\frac{22}{26}$ & $\frac{220}{140}$ & $\frac{0,7}{0,5}$ & $\frac{1,8}{3,4}$ \\
\hline
\end{tabular}

As a result of long wreckhouse wind in June 2017 the growing stock of the stands in the Park as well as relative density went down, while the level of windfall increased. Characteristic feature of fallen trees was the category of its condition - mainly $2^{\text {nd }}, 3^{\text {rd }}, 4^{\text {th }}$. The presence of the following defects and diseases was brought out: pitch streak, rots, touchwood, side drought of stems, frost clefts. The largest area of windthrow and windbreak was found in the city part of the Park. The area damaged by wind storm has an elongated form and stretches lengthwise into three compartments, qu. 29, 30, 31 (pic. 1), including stands with predominance of silver birch, small-leaved lime and Scots pine. 


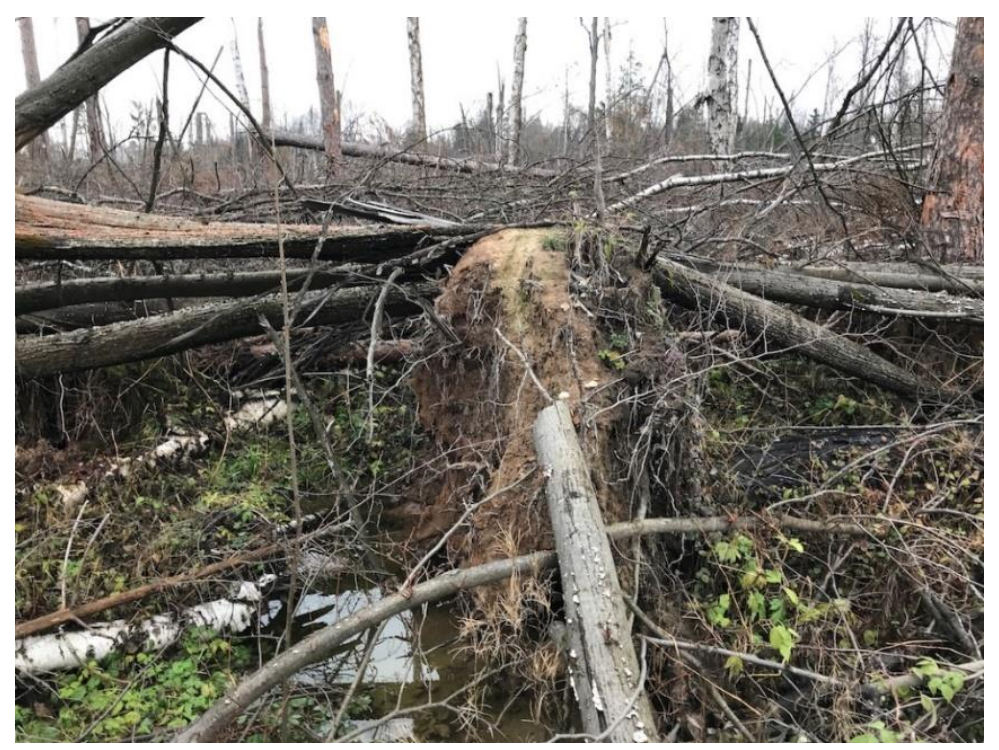

Fig. 1. Windthrow in qu. 29, 30, 31 of Losinoostrovsky Park (clearance between qu. 29 and qu. 30)

Uncleaned clusters of windthrow and windbreak deteriorate sanitary condition of the territory and increase the probability of forest fires as well as hot spots of diseases and pests.

Wind sustainability goes down as well in case of spreading rot diseases (for Norway spruce), which in turn is related to the high percentage of even-aged overmature stands and man-made plantations (table 3).

Table 3. State estimation of tree species most susceptible to windthrow and windbreak

\begin{tabular}{|c|c|c|c|c|}
\hline Species & $\begin{array}{c}\text { Point of } \\
\text { condition } \\
\text { category }\end{array}$ & $\begin{array}{c}\text { Current } \\
\text { mortality, } \% \\
\text { from normal } \\
\text { value }\end{array}$ & Diseases & Other reasons for \\
weakness
\end{tabular}

Birch stands in the national Park in general can be described as weak of having a tendency to become weak. The damage level is from 17 to $20 \%$ (in terms of damaged stems).

Lime has the best sanitary condition out of all deciduous trees. Current mortality does not exceed the normal values. Reasons of certain lime weakness could be natural ageing and high recreational loads.

Forest pathological data about spruce stands in the city part of the Park show that almost all spruce stands of 60 years and older are damaged by butt rot, which is the reason for high wind damage of this species. Similar situation happened while estimating consequences of 
windthrow of 1904 and 2001 year. One can suppose that old spruce stands in the city part of the Park were also damaged by butt rot.

European larch condition in general can be described as weak, average condition category is 1.6-1.9, current mortality is 5-10 times bigger than natural. Due to the fact that European larch is not shade tolerant, thickness of plantations led to crown deformation crowns are formed only within the lightened part of the stem, as a rule at the very top. We can notice honey fungus damage on European larch, which leads to rot development.

As a result of the examination it was stated that stands in the city part of the Park are susceptible to a number of diseases which decreases its sustainability to external factors.

On the areas damaged by windthrow and windbreak the evaluation of natural regeneration success was done. On these plots undergrowth is represented mainly by four species - small-leaved lime, Norway maple, Norway spruce, European oak in different proportions. Small-leaved lime undergrowth is mainly of coppice origin, is located in groups close to parent tree and has acini form stem bend. Among the undergrowth tree species, we can see Silver birch and common elm (Ulmus Laevis Pall.). The condition of most undergrowth trees is unsatisfactory. Partly it is damaged by entanglement of falling trees crowns, and partly while clearing windfall.

Occurrence coefficient $\mathrm{Kв}$ (\%) of main forest forming species is from 0.51 (for Norway spruce) to 0.76 (for Norway maple), which indicates uneven distribution of undergrowth on the territory of damaged stand as well as necessity of planting design.

The highest percentage of undergrowth viability is for Norway maple (83\%), the lowest - for European oak (27\%). Condition category of oak undergrowth varies from 2.0 to 2.6, its condition is estimated as weak or seriously weak. Mortality exceeds the normal values 3 and more times. It happens mainly due to die-back of lower layer trees as a result of shade and powdery mildew damage, which breaks the process of photosynthesis.

While estimating natural regeneration an undergrowth quality coefficient for main forest forming species on areas damaged by windthrow and windbreak was defined: for Norway spruce it was 0.37 (satisfactory), for European oak - 0.19 (unsatisfactory), for Norway maple -0.51 (good), for small-leaved lime -0.34 (satisfactory).

As a result of monitoring forest areas in the city part of the Park the impact analysis of morphological parameters on tree wind resistance was made.

The following characteristics describing tree morphology were considered: crown parameters (length, width, windage area defined as ellipse area) as well as a number of relative indicators - relation of stem diameter to its height, relative crown length (relation of crown length to tree height), relation of crown length to its width (degree of branching) and relation of windage area to a stem diameter characterizing relative intensity of mechanic load on stem. On $2 / 3$ of areas fallen trees are characterized by wide and branched crown while having a small diameter.

In order to find the connection between variables a correlation analysis was conducted, as a result of which a positive dynamic was found between the value of damaged trees and average diameter of fallen trees (0.6), degree of rot damage (0.89), crown length (0.64). These indicators were included into a model of multiple regression analysis and a graph was built to show the relation between grouped statistic and forecast data about the amount of windfall (pic. 2):

$$
V_{\text {в }}=32,571-0,376 \cdot d+0,378 \cdot f+0,833 \cdot \text { Lкр, }
$$

Where $\mathrm{V}_{\mathrm{B}}$ is an amount of windfall, \%; diameter of a fallen tree to an average diameter of windfall, $\% ; \mathrm{f}-$ rot, $\%$; $\mathrm{L}_{\mathrm{kp}}$ is relative crown length, $\%$.

Coefficient of multiple determination equals to 0.97 . It means that in $97 \%$ of cases out of $100 \%$ the change in volume of fallen trees depends on the factors included in the equation. Only $3 \%$ of cases change of fallen area is related to other random factors. Standard error equals to $5.9 \%$. 


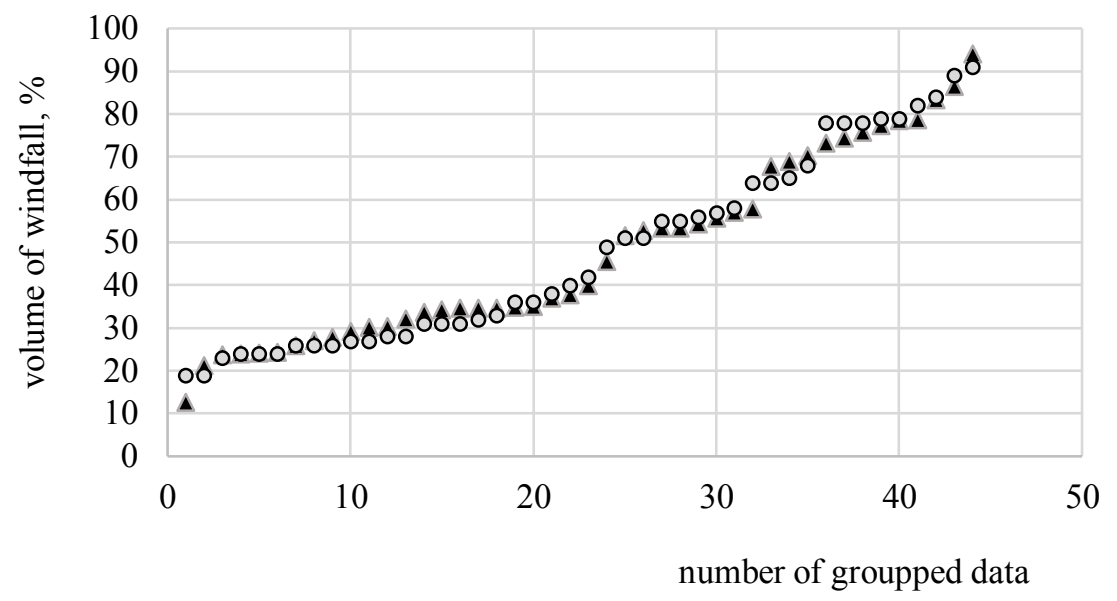

Statistics data

Forecast data

Fig. 2. Correlation of statistic and forecast data of windfall volume

Based on the equation and the graph showing correlations of statistic and forecast data of windfall volume we can draw a conclusion that crown length, stem diameter and rot presence have the highest influence on intensity of wind damage.

The model was compiled on the basis of data, collected for birch stands. Nevertheless, model testing on other species (small-leaved lime, European larch) showed that errors in predicting area of fallen trees are within the allowable limits as well as that it can be used for other tree species. When the level of rot damage increases, the smaller the diameter of stands with the same crown area is, i.e. the bigger the relation of windage area to stem diameter is, the higher the percentage of fallen trees is.

\section{Discussion}

Similar studies have been conducted by Pretzsch H., Schwaiger F., Maltamo M., Feldmann E.and other scientists [3-14]. Many researchers pay attention to developing approaches to forest management that take into account current climate and vegetation changes [15-16].

Evaluation of Moscow region forests condition is the subject of numerous researches, among them of a high popularity is the development specialists Center of Forest Ecology and Productivity of the Russian Academy of Sciences of criteria and indicators of forest sustainable development, which allows us to evaluate changes in forest management. The condition of forest ecosystem in the Park was evaluated as average (percent of forested area $-36 \%$, size of forested area $-7.4 \mathrm{~km}^{2}$, density of Red List forest species $-0.12 \mathrm{sp} / \mathrm{km}$ ) with low Action level (1 out of 5) as well as with high level of load.

A number of factors decreasing sustainability of stands in the Park was found: predominance of mature and ovrmature stands having 9-10 units of the same species, mass spread of diseases, mainly unsatisfactory natural regeneration of forest forming species.

Weak trees of 1 growth class suffered from damage. According to the result of regression analysis the most important factors influencing trees sustainability are its diameter, crown length and rot presence. Crow sizes identifying windage area and load on stem are important in relation to the stem diameter. 
Examination of forest cover in the areas of fallen trees showed that even visually we can see the indicators of stagnant waterlogging. On the areas damaged by windthrow and windbreak there are plants indicating the process of grassing-down: lime grass (Deschampsia cespitosa (L.) P. Beauv, bush grass (Galamagrostis epigejos (L.) Roth, slender sedge (Carex pilosa Scop.).

\section{Conclusion}

The tasks imposed on the Park, include restoration of damaged landscapes and biogeocenose, forest conservation, protection and regeneration as well as development and implementation of scientific methods of nature conservation. While forming stands on areas damaged by windthrow and windbreak in order to restore the structure and composition of native types of forest it is necessary to consider individual forest growth conditions of each compartment. Isolation of plants environment leads to the necessity of artificial regeneration of one species of woody-bushy vegetation as well as regulating others. Taking into account obtained results it is worth conforming to a practical approach:

creating a stand with multi-level vertical structure and composite mosaic space location of plots with predominance of different species;

organizing a subsidiary tree nursery or a subdivision in order to supply own needs with standard sustainable planting material for main forest forming species;

organizing artificial regeneration if there is no possibility of having combined or natural one.

Scientific novelty of the research conducted is the following:

valid choice of factors influencing the intensity of stand damage by windthrow and windbreak;

development of a regression analysis model allowing to forecast the volume of damaged stands on wind exposure;

forming an approach to conduct practical treatments promoting higher sustainability of stands and better quality of forest restoration measures.

\section{References}

1. A. Muscolo, S. Bagnato, M. Sidari, R. Mercurio, Journal of Forestry Research 25, 725736 (2014). DOI: 10.1007/s11676-014-0521-7.

2. V. V. Kiseleva, Forest Bulletin Vol. 23 (2), 20-28 (2019). DOI: 10.18698/2542-14682019-2-20-28

3. H. Pretzsch, M. Steckel, M. Heym et al., Eur J Forest Res (2019). https://doi.org/10.1007/s10342-019-01233-y

4. H. Pretzsch, M. del Río, C. Ammer, et al., Eur J Forest Res 134, 927-947 (2015). https://doi.org/10.1007/s10342-015-0900-4

5. F. Schwaiger, W. Poschenrieder, P. Biber and H. Pretzsch, Forests 9 (10), 632 (2018). https://doi.org/10.3390/f9100632

6. J. Dieler, E. Uhl, P. Biber, J. Müller, T. Rötzer and H. Pretzsch, Eur J Forest Res 136, 739-766 (2017). https://doi.org/10.1007/s10342-017-1056-1

7. M. Maltamo, A. Pesonen, L. Korhonen et al., Ecosyst 2, 12 (2015). https://doi.org/10.1186/s40663-015-0037-4

8. L. Dong, X. Jin , T. Pukkala et al., Eur J Forest Res 138, 789-801 (2019). https://doi.org/10.1007/s10342-019-01196-0 
9. E. Martínez del Castillo, L.A. Longares, R. Serrano-Notivoli et al., Eur J Forest Res 138, 299-312 (2019). https://doi.org/10.1007/s10342-019-01169-3

10. Y. Yang, S. Huang, Eur J Forest Res 137, 153-167 (2018). https://doi.org/10.1007/s10342-017-1095-7

11. T. Wohlgemuth, R. Schwitter, P. Bebi et al., Eur J Forest Res 136, 1029-1040 (2017). https://doi.org/10.1007/s10342-017-1031-X

12. J. Dieler, E. Uhl, P. Biber et al, Eur J Forest Res 136, 739-766 (2017). https://doi.org/10.1007/s10342-017-1056-1

13. J. Stoltz, Y. Lundell, E. Skärbäck et al., Eur J Forest Res 135, 803-813 (2016). https://doi.org/10.1007/s10342-016-0974-7

14. S. Condés, M. del Río, Eur J Forest Res 134, 1095-1108 (2015). https://doi.org/10.1007/s10342-015-0912-0

15. E. Nordström, M. Nieuwenhuis, E.Z. Başkent et al., Eur J Forest Res 138, 561-581 (2019). https://doi.org/10.1007/s10342-019-01189-z

16. E. Feldmann, J. Glatthorn, M. Hauck et al., Eur J Forest Res 137 (3), 321-335 (2018) https://doi.org/10.1007/s1034 2-018-1105-4 